\title{
A fitness assessment study among young fishermen of coastal areas of East Midnapore District of West Bengal, India
}

\author{
Pallav Sengupta ${ }^{\prime}$, Sobhana Sahoo ${ }^{2}$ \\ ${ }^{1}$ Lecturer; ${ }^{2}$ Head \& Associate Professor; Department of Physiology, Vidyasagar College for Women, \\ University of Calcutta, Kolkata, West Bengal, India.
}

\begin{abstract}
Being the fourth most populated state of India, West Bengal has a population of about 82 million, of which a major percentage is represented by coastal fishing communities who are habituated to do a physically demanding occupation which may have a positive influence on their the physical parameters. Thus the present investigation was designed in order to assess the influence of fishery, such a physically demanding occupation on physical fitness and to compare whether fishermen have more cardiovascular fitness and anaerobic power than sedentary workers or not. The study was conducted in 15 randomly selected male fishermen of the Midnapore District (East), West Bengal, India (mean age of $22.5 \mathrm{yrs}$ ), and the 15 college students (mean age of $21.9 \mathrm{yrs})$ served as a control group. A significant difference $(\mathrm{p}<0.05)$ in blood pressure, PFI, energy expenditure, body fat $\%$ and anaerobic power was found in fishermen. But, in contrast, BSA, BMI, resting heart rate, $\mathrm{VO}_{2 \max }$, mean upper arm circumference, thigh and calf circumferences were found to be non-significant. This study implies that fishermen have more physical fitness (cardiovascular fitness) and muscle mass, but a lower percentage of body fat than the sedentary population.
\end{abstract}

Keywords: Physical fitness, Anaerobic power, $\mathrm{VO}_{2 \max }$, body fat, Fishermen, Harvard Step Test, West Bengal.

\section{Introduction}

West Bengal is the fourth most populated state situated in the Eastern Region of India, 82 million people stay in the State. It is $2.7 \%$ of India's area but about $7.8 \%$ of the country's population. This state ranks first in terms of density of 904 per sq. $\mathrm{km}$ as per the 2001 census. The boundaries of the state are Nepal, Bhutan and the Sikkim on the North, Goalpara district of Assam and Bangladesh on the East, Orissa and the Bay of Bengal on the South and Bihar on the West. The coastal area of West Bengal is the home of some of the poorest people, living in some of the least served and remote areas of the State; the 3 coastal districts i.e. South and North 24 Parganas and Purba (East) Midnapore. ${ }^{1}$ Fishery is considered as one of the brightest and most prosperous industries in India. ${ }^{2}$ Among the population of the 82 million peoples of West Bengal, (census, 2001) more than 2.4 million are fishers who live in West Bengal (whereas 33 million people are involved in fishing in India) (Table 1).,

The occupation of fishing demands physical fitness, but the health status and physical fitness data of fishermen of India is scanty. A literature review of the fishing industry revealed

\section{Practice points}

- Fishing is the occupation of a major percentage of people residing in coastal West Bengal, India.

- Fishermen are habituated to do a physically demanding job which may have some influence on their physical parameters, but reports on this are quite scanty.

- The findings of the present investigation showed young fishermen have a greater PFI, lower $\mathrm{BF} \%$, greater anaerobic power and less energy expenditure.

- This study indicates that the physically demanding job of fishermen is positively related with their physical fitness.

- This study implies that the fishermen have more physical fitness and muscle mass, but a lower percentage of body fat than the sedentary population.

that there have been limited studies conducted among fishermen and the majority of studies focused on mortality

Correspondance: Pallav Sengupta, Lecturer, Department of Physiology, Vidyasagar College for Women, University of Calcutta, 39, Sankar Ghosh Lane, Kolkata 700 006, West Bengal, India. E-mail: sunny pallav_1984@yahoo.co.in. 
Table 1: West Bengal and its fishing communities: At a glance

\begin{tabular}{|l|l|}
\hline Location & $\begin{array}{l}\text { Latitude 210 38' N 270 10' N } \\
\text { Longitude 85038' E - 89050' E }\end{array}$ \\
\hline Total area & 88551.0 Sq. km \\
\hline Total population* & 82 million \\
\hline Fishermen's villages & 11200 \\
\hline $\begin{array}{l}\text { Marine villages } \\
\text { Fishermen population }\end{array}$ & 652 \\
& $\begin{array}{l}\text { Inland- 22,12,019 } \\
\text { Marine- 2,62,318Total 24,74,337 }\end{array}$ \\
\hline
\end{tabular}

*As per 2001census

rates and accidents. ${ }^{5}$ Moreover, many of the studies examined the specific aspects of fishermen's health. ${ }^{6.7}$ It is also difficult to generalize the findings of the studies conducted in the $\mathrm{UK}^{8}$, Scotland ${ }^{6}$ and Australia ${ }^{7}$. Fishermen in other parts of the world are often involved in different types of fishing, and may experience different health and safety problems. Additionally, the majority of studies were conducted 20 years ago and several over $30-40$ years ago, ${ }^{8-10}$ further reducing their relevance to the present day. Somewhat recent studies on seafarers and fishermen boarding ships showed severe obesity, leading to a decline in physical fitness which may interfere with the performance of daily duties and also constitute a safety issue in case of an emergency. ${ }^{11}$ In addition, the increased risk of acute disease or acute complications to a chronic condition without access to professional medical assistance may become a problem. Previous research indicates that overweight is of major importance in some sectors of the maritime industry. ${ }^{11,12}$ It is known that physical fitness not only refers cardiorespiratory fitness and muscular strength, but also coordination and flexibility i.e. the full range of physical qualities which can be understood as an integrated measurement of all functions and structures involved in the performance. ${ }^{13}$ In adults, low physical fitness (principally cardiorespiratory fitness) seems to be a stronger predictor of both cardiovascular and all-cause mortality than any other well established risk factors. ${ }^{14}$ To a large extent, habitual physical activity levels among workers vary depending on the type of work performed. When the work is not of a sedentary nature, a large proportion of habitual physical activity is performed at the workplace. ${ }^{15}$ Such a type of job has been performed by the fishermen who need excellent muscular strength and better cardiovascular fitness in their occupation. Work in commercial fishing is physically demanding, but unlike merchant seamen, fishermen are not required to hold a certificate of medical fitness. Thus the aim of this study was to determine the influence of such occupational physical work volumes on fitness parameters, and to test the hypothesis that physically demanding jobs have a positive influence on the physical fitness of workers.

\section{Methods}

Selection of subjects

Two groups of 15 non-smoker male subjects between 18-25 years of age are randomly selected to participate in the present study. Subjects of one group are young fishermen (22.5 \pm 2.97 years) selected randomly from fishermen slum of Midnapore (East) District, West Bengal, India; other group consists of college students (21.9 2.16 years) (control). Subjects were instructed to take their last meal at least two hours before conducting the test in order to avoid the specific dynamic action (SDA) of food. All the experiments were carried out and measurements were taken in temperature of $20^{\circ}-25^{\circ} \mathrm{C}$ and relative humidity of about $45-50 \%$ in the winter season in India, both for control subjects and fishermen, to avoid a seasonal influence on fitness pattern. To minimize the experimenter bias, each measurement was taken three times and the mean was represented as the final result. Subjects with any type of disease, specially cardiac and respiratory ailments were not taken for experiments, only healthy subjects were considered for each experiment. Each subject was given sufficient rest before each experiment to get an accurate result.

\section{Assessment body mass index (BMI)}

The body mass index (or Quetelet Index) is the statistical measure which compares a person's weight and height by the following formula: ${ }^{16,17}$

$$
B M I=\text { Mass }(\mathrm{kg}) /(\text { Height in } \mathrm{m})^{2}
$$

The $\mathrm{WHO}^{18}$ regards a BMI of less than 18.5 as underweight and may indicate malnutrition, an eating disorder, or other health problems, while a BMI greater than 25 is considered overweight and above 30 is considered obese.

\section{Body fat \% measurement (From BMI, age and gender)}

Body fat can be estimated from BMI. There is a linear relationship between densitometrically-determined body fat percentage $(\mathrm{BF} \%)$ and $\mathrm{BMI}$, taking age and gender into account. Based on which following prediction formulas have been derived which showed a valid estimates of body fat at all ages, in males and females. But, in obese subjects, the prediction formulas are slightly overestimated. The prediction error is comparable with other methods of estimating body fat percentage, such as skinfold thickness measurements or bioelectrical impedance. ${ }^{19-21}$

The following formula ${ }^{19}$ was used to predict body fat percentage is based on current BMI, age, and gender:

$$
\begin{gathered}
\text { Adult Body Fat } \%=(1.20 \times \text { BMI })+(0.23 \times \text { Age })-(10.8 \times \\
\text { gender })-5.4
\end{gathered}
$$

Gender values for male $=1$, female $=0$ 
Body surface area (BSA)

Body surface area (BSA) represents the measured or calculated surface of a human body. Various calculations have been published to get BSA without direct measurement.

The Dubois and Dubois formula ${ }^{22}$ was used for estimating BSA.

$$
B S A\left(\mathrm{~m}^{2}\right)=0.007184 \times \text { Weight }(\mathrm{kg})^{0.425} \times \text { Height }(\mathrm{cm})^{0.725}
$$

\section{Resting heart rate}

Baseline HR was obtained after five minutes rest in the sitting position. The resting heart beat was measured at carotid pulse. When two successive heart rate scores became equal then it was considered as resting heart rate. ${ }^{23}$

\section{Blood pressure}

Arterial pressure is most commonly measured by a sphygmomanometer, which historically used the height of a column of mercury to reflect the circulating pressure. ${ }^{24} \mathrm{BP}$ values were obtained after five minutes rest in the sitting position. $^{25}$

\section{Physical fitness index (PFI)}

PFI was calculated by measuring heart rate after performing Harvard step test (HST) developed by Brouha et al. in the Harvard Fatigue Laboratories using long form PFI equation. ${ }^{26}$ But, following modified HST under Indian conditions, a $51 \mathrm{~cm}$ high stool was used and the subjects stepped up and down at a rate of 30 cycles/min for 3 minutes or up to exhaustion. Exhaustion is defined as when the subject cannot maintain the stepping rate for 15 seconds. ${ }^{27,28}$ The recovery pulse was counted at 1 to $1.5,2$ to 2.5 and 3 to 3.5 minutes of recovery.

Long from Equation - Fitness Index

$100 \mathrm{x}$ Test Duration in Second

$200 \times$ Recovery heart rates ( 1 to 1.5 mins +2 to 2.5 mins +
3 to 3.5 mins)

\section{Anaerobic power test by Margaria double step method}

It is a short-term anaerobic test or power test in which the subject is taking two steps at a time, the height of the stairs are measured by measuring tape. To calculate the anaerobic power; the height of ascend, the body weight, and the duration (sec) is noted by the stopwatch. ${ }^{29}$ At first the work done is calculated by the following formulae:

$$
\text { Work done }=\text { body weight } \times \text { height } \text { of ascend } \times 0.002342
$$

From the calculated work done the anaerobic power $(\mathrm{kg} / \mathrm{meter} / \mathrm{sec})$ is obtained by the following formulae:

Anaerobic power $=$

Work Done (Kg/mitre)

Duration (Sec)

\section{Determination of aerobic capacity $\left(\mathrm{VO}_{2 \max }\right)$}

It is the maximum amount of oxygen consumed during rhythmic dynamic progressively increasing exercise done by any kind of ergometer (treadmill, stationary bicycle ergometer, hand cranking etc.) at sea level under thermally neutral condition when more muscle mass recruited then capacity of $\mathrm{O}_{2}$ is increased. Nomogram of Astrand was used to determinate the $\mathrm{VO}_{2 \max }{ }^{30}$

\section{Energy expenditure (EE)}

Energy expenditure for any kind of job is normally measured by different calorimetric methods. It has also been determined by predictive formula. ${ }^{31}$

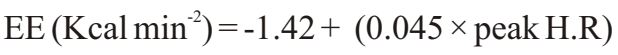

\section{Nutritional anthropometric measures}

Curvilinear distances (circumferences) taken around the midpoint of mean upper arm (MUAC), mid-thigh (TC), calf muscle of leg (CC), waist (WC) and buttock (BC). WC and $\mathrm{BC}$ are used to predict the body fat content. UAC is an index of body Energy store and protein mass. Sometime it is combined with skin fold thickness to calculate the areas of arm muscle and adipose tissue. TC indicates muscle atrophy due to disease or atrophy and CC provides an estimate of cross-sectional and adipose tissue areas of calf. ${ }^{32}$

\section{Statistical analysis}

Data was expressed as mean \pm SD. Comparison of parameters between control and fishermen was done by two tailed unpaired $t$-test, using Microsoft Excel 2007 and the result was considered as significant when the two-tailed $p<0.05$. $^{33}$

\section{Results}

The height $(\mathrm{cm})$ and body weight $(\mathrm{kg})$ of 15 control subjects were $164.4 \pm 7.20$ and $59.1 \pm 7.2($ mean $\pm \mathrm{SD})$ respectively and those of young fishermen were $156.6 \pm 4.41$ and $51.6 \pm 8.4$ (mean $\pm \mathrm{SD}$ ) respectively. Results are represented in Table 2 to Table 5 .

Table 2 shows other than $\mathrm{BF} \%$ no significant differences were found in the physical parameters between two groups. The physical fitness index (PFI) score reveals that young fishermen have excellent physical fitness level (Table 3).

Table 2: Physical parameters of control subjects and young fishermen

\begin{tabular}{|l|c|c|c|}
\hline & $\begin{array}{c}\text { Control } \\
(\mathrm{n}=15)\end{array}$ & $\begin{array}{c}\text { Fishermen } \\
(\mathrm{n}=15)\end{array}$ & p values \\
\hline BMI $\left(\mathrm{Kg} / \mathrm{m}^{2}\right)$ & $21.7 \pm 1.93$ & $19.2 \pm 2.40$ & 0.101 \\
\hline Body Fat \% & $20.5 \pm 1.73$ & $17.7 \pm 3.06$ & $0.007^{*}$ \\
\hline BSA $\left(\mathrm{m}^{2}\right)$ & $1.68 \pm 0.08$ & $1.62 \pm 0.06$ & 0.609 \\
\hline
\end{tabular}

Values are mean $\pm \mathrm{SD}$; ${ }^{*}$ Values are significant $p<0.05$. 
Table 3: Physical fitness variables of control and fishermen

\begin{tabular}{|l|c|c|c|}
\hline & $\begin{array}{c}\text { Control } \\
(\mathrm{n}=15)\end{array}$ & $\begin{array}{c}\text { Fishermen } \\
(\mathrm{n}=15)\end{array}$ & p values \\
\hline $\begin{array}{l}\text { Resting Heart Rate } \\
\text { (beats/min) }\end{array}$ & $76.2 \pm 8.10$ & $73.5 \pm 4.051$ & 0.453 \\
\hline $\begin{array}{l}\text { Systolic Blood } \\
\text { Pressure (mm Hg })\end{array}$ & $114 \pm 4.6$ & $24.2 \pm 7.92$ & $0.003^{*}$ \\
\hline $\begin{array}{l}\text { Diastolic Blood } \\
\text { Pressure (mm Hg) } \\
\text { PFI }\end{array}$ & $74.1 \pm 6.8$ & $78.0 \pm 5.25$ & 0.102 \\
\hline
\end{tabular}

Values denote mean $\pm \mathrm{SD}$; ${ }^{*}$ Values are significant $p<0.05$.

Table 4 mainly represents the comparative aspect of anaerobic power, energy expenditure and $\mathrm{VO}_{2 \max }$. Fishermen showed greater anaerobic power, but less energy expenditure than the control subjects. They showed no significant difference in $\mathrm{VO}_{2 \max }$.

Table 4: Comparison of anaerobic power, $\mathrm{VO}_{2 \max }$ and energy expenditure between control and fishermen

\begin{tabular}{|l|c|c|c|}
\hline & $\begin{array}{c}\text { Control } \\
(\mathrm{n}=15)\end{array}$ & $\begin{array}{c}\text { Fishermen } \\
(\mathrm{n}=15)\end{array}$ & p values \\
\hline $\begin{array}{l}\text { Anaerobic power } \\
\left(\mathrm{kg} \cdot \mathrm{m}^{-1} . \mathrm{sec}^{-1}\right)\end{array}$ & $12.3 \pm 2.46$ & $15.0 \pm 2.55$ & $0.027^{*}$ \\
\hline $\mathrm{VO}_{2 \max }\left(\right.$ liters.min $\left.\mathrm{min}^{-1}\right)$ & $3.12 \pm 0.33$ & $3.27 \pm 0.57$ & 0.093 \\
\hline $\begin{array}{l}\text { Energy expenditure } \\
\left(\mathrm{K} . \mathrm{Cal} . \mathrm{min}^{-2}\right)\end{array}$ & $5.67 \pm 0.57$ & $4.35 \pm 0.66$ & $0.002^{*}$ \\
\hline
\end{tabular}

Values denote mean $\pm \mathrm{SD} ;{ }^{*}$ Values are significant $p<0.05$.

Table 5 represents the anthropometric measures of both groups which may affect fitness pattern. But these parameters showed no significant difference $(p>0.05)$ with control subjects.

Table 5: Comparison of anthropometric measures between control and fishermen

\begin{tabular}{|lcc|}
\hline Group & $\begin{array}{c}\text { Control } \\
(\mathrm{n}=15)\end{array}$ & $\begin{array}{c}\text { Fishermen } \\
(\mathrm{n}=15)\end{array}$ \\
$\begin{array}{l}\text { Mean Upper Arm } \\
\text { Circumference }(\mathrm{cm})\end{array}$ & $27.3 \pm 4.17$ & $28.5 \pm 2.64$ \\
Thigh Circumference $(\mathrm{cm})$ & $47.4 \pm 5.52$ & $46.2 \pm 4.56$ \\
Calf Circumference $(\mathrm{cm})$ & $32.4 \pm 3.81$ & $34.5 \pm 2.10$ \\
Waist Circumference $(\mathrm{cm})$ & $75.6 \pm 4.50$ & $72.3 \pm 5.55$ \\
Buttock Circumference $(\mathrm{cm})$ & $81.0 \pm 6.06$ & $76.5 \pm 4.14$ \\
Waist-to-Hip ratio & $0.94 \pm 0.02$ & $0.92 \pm 0.01$ \\
\hline
\end{tabular}

Values denote mean \pm SD.

\section{Discussion}

Our nation's young people are, in large measure, unfit and increasingly overweight. In long run this physical inactivity may enhance risk of cardiovascular diseases and deaths. The percentage of young people who are overweight has doubled since last two decades. Whereas some reports describes poor nutritional status of young individuals in India that resulted in their less body weight. In West Bengal more than $22 \%$ of people are reported to be underweight, ${ }^{34}$ but, the result of present study reveals that physical parameters (BMI, BSA) of fishermen did not significantly differ from control group, which may be due to their young age; hence tend to be lean rather than obese. But, young fishermen were found to have less body fat percentage than sedentary population (Table 2). Earlier findings of authors have also showed similar results in case of fishermen of coastal Orissa. ${ }^{35}$ Some other reports, such as a study on fishermen of Pondicherry, similarly showed almost 50.5\% of fishermen have BMI within normal range while undernutritioned fishermen are $36.5 \%$ and obese are only $1.9 \%{ }^{36}$ The higher BMI in control subjects in the present study may be attributable to their greater weight and is consistent with findings from other studies. ${ }^{37-39}$ The BMI is an index of weight adjusted for stature. It is one of the most useful tools for diagnosing obesity or malnutrition. However, such a diagnosis should take into account a person's age, sex, fitness and ethnicity. The result of the present study implies no such difference in physical characteristics among two young populations.

Cardiorespiratory fitness is a measure of how well a physiological system is able to transport oxygen to your muscles during prolonged exercise. Resting heart rate and aerobic capacity or maximum oxygen uptake capacity $\left(\mathrm{VO}_{2 \max }\right)$ have been widely considered to be reliable and valid measure of cardiorespiratory or aerobic fitness ${ }^{35,40}$ along with endurance. ${ }^{41}$ As fishermen normally perform work related to muscular strength, no significant change was found in these parameters. This result may have some correlation with the findings of Bailey et $a l^{42}$ who have found that lower $\mathrm{VO}_{2 \max }$ levels in men were associated with an increased probability of being overweight or obese. Therefore it can be presumed that normal body weight of fishermen in present study thus may have not influenced over this parameter. Strength exercise increases ventricular muscle mass ${ }^{43}$ which results in increased force of contraction and hence cardiac output which may be the cause significant increase of blood pressure. ${ }^{44}$ Conversely, studies on fishermen of Pondicherry showed they are less prone for higher systolic pressure whereas they were more prone for high diastolic blood pressure. In their study, they showed proportion of fishermen with optimal and normal systolic blood pressure was $76.3 \%$ and $67.2 \%$ respectively. ${ }^{36}$ Some studies also revealed impact of BMI on blood pressure; they have showed with the increase of BMI a drastic increase in systolic and diastolic blood pressure, unalike the findings of present study. ${ }^{45}$ 
PFI scores are useful measure of fitness for strenuous exercises. Physical fitness has three main aspects: static fitness (absence of disease), dynamic fitness (ability to perform strenuous work) and motor skills fitness. Of these three, dynamic fitness is very important and can be measured by the Harvard Step Test. As fishermen are habituated to do this strenuous job, i.e. they perform heavy muscular work regularly, their pulse rate recovered quickly which is an indicator of better fitness and is reflected in a significantly higher PFI (Table 3) and lower energy expenditure and they also have better anaerobic power than sedentary workers (Table 4). These results are very much similar to the earlier findings in fishermen of coastal Orissa. ${ }^{35}$

As young fishermen perform heavy work, so they should have more mean upper arm circumference than control subjects which is an estimate of energy store and protein mass of the body which is an indirect estimate of strength, but no significant difference was observed in mean upper arm circumference (MUAC) between two groups. Waist-tohip ratio ${ }^{46}$ is found to be insignificant in fishermen than control subjects which are another indicator of less fat percentage in fishermen than control subjects, which is caused by their poor nutritional status, which again attributable to their economic condition. ${ }^{47}$ BMI along with waist circumference have been used to evaluate health risks associated with obesity, because fats redistributes centrally with increases in waist circumference and results in altered waist-to-hip ratio. However, no significant difference was also found in thigh and calf circumference between two groups (Table 5).

\section{Conclusion}

Hence it may be concluded from the present study that physical anthropometric parameters (height, weight, BSA, BMI, waist-to-hip ratio) along with were found to be within expected range of normal in both group of subjects. But fitness variables (PFI, energy expenditure and anaerobic power) showed better result in young fishermen. Thus, this study indicates that the physically demanding job of fishermen is positively related with their physical fitness. But, for better health, not only fitness but physical endurance is also recommended.

\section{Acknowledgement}

Authors want to acknowledge the Principal, Vidyasagar College for Women, University of Calcutta for providing support to the authors for this work. They also gratified to other Teachers and Staffs of Department of Physiology, Vidyasagar College for Women and obvious credit goes to B.Sc. Final Year Physiology Honours students (2010-2011) and the fishermen of Midnapore District (East), West Bengal, India for their kind co-operation in conducting the investigation.

\section{Disclosure}

The authors report no conflicts of interest in this work.

\section{References}

1. The International Fund for Agricultural Development (IFAD) Report. Republic of India: West Bengal Coastal Areas Development Project-Inception Phase. India, IFAD, 2007.

2. Fishing Industry in India, Indian Industries. Indianetzone.http://www.indianetzone.com/46/fishin $\mathrm{g}$ industry india.htm (accessed Oct 2011).

3. Jacob T, Venkataraman G, Alagaraja K, Dharmaraja SK. Manpower and fishing equipment available and exploited fishery resources in the coastal waters of India. Harvest and Post-harvest technology of Fish. Cochin: Society of Fisheries Technologists, 1985.

4. DOF, GOWB. Hand Book of Fisheries Statistics. Unpublished data from DOF 2003-04.pp. 12.

5. Matheson CI, Morrison S, Murphy E, Lawrie T, Ritchie $\mathrm{L}$ and Bond $\mathrm{C}$. The health of fishermen in the catching sector of the fishing industry: a gap analysis. Occul Med 2001;51:312-7.

6. Rix KJB, Hunter D and Olley PC. Incidence of treated alcoholism in north-east Scotland, Orkney and Shetland fishermen, 1966-1970. Brit J Indus Med 1982;39:11-7.

7. Driscoll TR, Ansari G, Harrison JE, Frommer MS and Ruck EA. Traumatic work related fatalities in commercial fishermen in Australia. Occup Env Med 1994;51:612-6.

8. Moore SRW. The mortality and morbidity of deep sea fishermen sailing from Grimsby in one year. Brit $J$ Indus Med 1969; 26: 25-46.

9. Dalgaard JB, Deckner F and Fallentin B. Fatal poisoning and other health hazards connected with industrial fishing. Brit J Indus Med 1972;29:307-16.

10. Cadenhead RM. Hospital admissions of fishermen from the fishing grounds around the Shetland Islands. $J$ Soc Occup Med 1976;26:127-31.

11. Hoeyer JL, Hansen HL. Obesity among Danish seafarers. Int Marit Health 2005; 56:48-55.

12. Tomaszewski R, Dymnicki P, Flasiński J et al. Studies on the risk of ischaemic heart disease in fishermen, seafarers and dockers. Bull Inst Marit Trop Med Gdynia 1990;41:21-6.

13. Castillo Garzon MJ, Ortega Porcel FB, Ruiz Ruiz J. Improvement of physical fitness as anti-aging intervention. Med Clin 2005;124:146-55.

14. Myers J, Prakash M, Froelicher V, Do D, Partington S, Atwood JE. Exercise capacity and mortality among men referred for exercise testing. $N$ Engl $\mathrm{J}$ Med 2002;346:793-801.

15. Ruzic L, Heimer S, Misigoj-Durakovic M, Matkovic BR. Increased occupational physical activity does not 
improve physical fitness. Occup Environ Med 2003;60:983-5.

16. Keys A, Fidanza F, Karvonen MJ, Kimura N and Taylor HL. Indices of relative weight and obesity. $J$ Chr Dis 1972;25:329-43.

17. Eknoyan G. Adolphe Quetelet (1796-1874) the average man and indices of obesity. Nephrol Dial Transplant 2008;23:47-51.

18. WHO: Global Database on Body Mass Index. BMI Classification.http://apps.who.int/bmi/index.jsp?intro Page $=$ intro 3.html (accessed Oct 2011).

19. Deurenberg P, Westrate JA, Seidell JC. Body mass index as a measure of body fatness: age- and sexspecific prediction formulas. Br J Nutr 1991;65:105-14.

20. Deurenberg P, Yap M, van Staveren WA. Body mass index and percent body fat. A metabolic analysis among different ethnic groups. Int J Obes Relat Metab Disord 1998; 22:1164-71.

21. Wellens RJ, Roche AF, Khamis HJ et al. Relationships between body mass index and body composition. Obes Res 1996; 4:35-44.

22. Dubois D, Dubois EF. A formula to estimate the approximate surface area if height and weight be known. Arch Intern Med 1916;17:863-71.

23. Khurana I. Medical physiology. $1^{\text {st }}$ ed. Noida: Elsevier, 2006.

24. Booth J. A short history of blood pressure measurement. Proceed Royal Soc Med 1977;70:793-9.

25. Chatterjee CC. Human Physiology. $10^{\text {th }}$ ed. Calcutta: Medical Allied Agency, 1985.

26. Brouha I, Health CW, Gray B. A step test simple method of measuring physical fitness for hard muscular work in adult men. Rev Canadian Biol 1943;2:86.

27. Ryhming I. A modified Harvard Step Test for Evaluation of Physical Fitness. Arbeitsphysiologie 1953; 15: 235-50.

28. Monotoye HJ. The Harvard Step Test and Work Capacity. Rev Can Biol 1953;11:491-9.

29. Margaria R, Aghemo P, Rovelli E. Measurement of muscular power (anaerobic) in man. J Appl Physiol 1966;21:1662-4.

30. Astrand PO, Rodahl K, Dahl H, Stromme S. Textbook of work physiology: Physiological bases of exercise. $4^{\text {th }}$ ed. Champaign, IL: Human Kinetics Publishers, 2003.

31. Datta SR, Ramanathan NL. Energy Expenditure in work predicted from Heart rate and pulmonary ventilation. J App Physio 1969;26:279-302.

32. Roy JS. Body composition in biological anthropology.
Cambridge Studies in Biological and Evolutionary Anthropology (No. 6). Cambridge: Cambridge University Press, 1991.

33. Das D, Das A. Statistics in Biology and Psychology. $4^{\text {th }}$ ed. Kolkata: Academic publishers, 2005.

34. Bisai S, Ghosh T, Bose K. Prevalence of underweight, stunting and wasting among urban poor children aged 1-5 years of West Bengal, India. Int J Curr Res 2010; 6:39-44.

35. Sengupta P, Sahoo S. A Cross-Sectional Study to Evaluate the Fitness Pattern among the Young Fishermen of Coastal Orissa. Ind J Pub Heal Res Dev (in press).

36. Government of Pondicherry. Fisheries at a glance. Pondicherry: Department of Fisheries, Government of Pondicherry, 1995.

37. Hammond J. Investigation into the characteristics of children with motor difficulties: An holistic approach. [thesis]. Armidale, NSW: University of New England, 1995.

38. Larkin D, Hoare D, Kerr G. Structure/function interactions: A concern in the movement impaired child. Poster presented at the 7th ISAPA International Symposium, Berlin. 1989.

39. O'Beirne C, Larkin D and Cable T. Coordination problems and anaerobic performance in children. Adapted Physical Activity Quarterly 1994;11:141-9.

40. Das KK, Dhundasi SA. Physical fitness: A longitudinal study among Muslim children of Bijapur (Karnataka). Ind J Physiol Pharmacol 2001;45:457-62.

41. Sengupta P. Assessment of Physical Fitness Status of Young Sikkimese Residing In High-Hill Temperate Regions of Eastern Sikkim under the influence of Climate and Socio-Cultural Factors. Asian J Med Sci 2011;2: 169-74.

42. Bailey DM, Davies B, Young IS. et al. EPR spectroscopic detection of free radical outflow from an isolated muscle bed in exercising humans. $\mathrm{J} \mathrm{Appl}$ Physiol 2003; 95: 1714-8.

43. Kanstrup L, Marving J, Høilund-Carlsen PF, Saltin B. Left ventricular response upon exercise with trained and detrained leg muscles. Scand J Med Sci Sports 1991;1:112-8.

44. Sengupta P, Sahoo S. Evaluation of Health Status of the Fishers: Prediction of Cardiovascular Fitness and Anaerobic Power. World J Life Sci Med Res 2011;1: 2530.

45. Svartberg J, Jorde R, Sundsfjord J, Bønaa KH, BarrettConnor E. Seasonal Variation of Testosterone and Waist to Hip Ratio in Men: The Tromsø Study. J Clin Endocrinol Metab 2003; 88:3099-104. 
46. Chand MG, Rao RS. Appraisal of Cardio Vascular Disease Risk Factors in a Costal Environment Fishermen's Urban Slum of Visakhapatnam. J Hum Ecol 2007;21:53-8.
47. Pal B, Chattopadhyay M, Maity M, Mukhopadhyay B, Gupta R. Income and nutritional status of fishing community residing in coastal Bay of Bengal. Anthrop Anz 2011;68:195-208. 